\title{
PENGELOLAAN PASAR KERENG PANGI DI DESA HAMPALIT KECAMATAN KATINGAN HILIR
}

\author{
Management of Kereng Pangi Market in Hampalit Village, Katingan Hilir District
}

\section{Karyadi* \\ Mirdo}

Universitas Muhammadiyah

Palangkaraya, Palangka Raya,

Central Kalimantan, Indonesia

email:

karyadi@umpalangkaraya.ac.id

\section{Kata Kunci: \\ Pengelolaan \\ Pasar \\ Keywords: \\ Management \\ Market}

\section{Accepted \\ January 2017}

\section{Published}

April 2017

\begin{abstract}
Abstrak
Penelitian ini bertujuan untuk mendeskripsi dan mnganlisis manajerial dalam Pengelolaan Pasar Kereng Pangi yang dilakukan oleh Dinas Koperasi, Usaha Kecil Menengah, Perdagangan dan Perindustrian Kabupaten Katingan. Metode yang digunakan dalam penelitian ini adalah metode kualitatif. Teknik penggumpulan data menggunakan cara wawancara, observasi dan dokumentasi. Teknik analisis data dalam penelitian ini menggunakan metode analisis data kualitatif dengan cara mereduksi data, menyajikan data dan memverifikasi/penarikan suatu kesimpulan mengenai Pengelolaan Pasar Kereng Pangi di Dinas Koperasi, Usaha Kecil Menengah, Perdagangan dan Perindustrian Kabupaten Katingan.

Hasil penelitian membuktikan bahwa Pengelolaan Pasar Kereng Pangi yang dilakukan oleh Dinas Koperasi, Usaha Kecil Menengah, Perdagangan dan Perindustrian Kabupaten Katingan masih belum maksimal berdasarkan indikator dalam penelitian ini yaitu I)Perencanaan, 2) Pengorganisasian, 3) Pengarahan dan 4) Pengendalian.
\end{abstract}

\begin{abstract}
This study aims to describe and managerial analysis of Kereng Pangi Market Management conducted by the Office of Cooperatives, Small and Medium Enterprises, Trade and Industry, Katingan Regency. The method used in this research is the qualitative method. The technique of collecting data uses interviews, observation, and documentation. The data analysis technique in this study uses qualitative data analysis methods by reducing data, presenting data and verifying/drawing conclusions regarding the Management of Kereng Pangi Market in the Cooperative, Small and Medium Enterprises, Trade, and Industry, Katingan Regency.

The results of the study prove that Kereng Pangi Market Management conducted by the Office of Cooperatives, Small and Medium Enterprises, Trade and Industry in Katingan Regency is still not optimal based on the indicators in this study, namely I) Planning, 2) Organizing, 3) Direction and 4) Control.
\end{abstract}

\section{PENDAHULUAN}

Dalam sistem perekonomian, pasar memegang peranan penting dalam menggerakkan ekonomi masyarakat Indonesia selain sebagai muara dari produk-produk rakyat, pasar juga berfungsi sebagai tempat untuk bekerja yang sangat berarti bagi masyarakat. Sejak zaman penjajahan kegiatan pasar beserta para pedagangnya berkembang secara alamiah.

Pasar tradisional merupakan pasar yang memiliki keunggulan bersaing secara alamiah yang tidak dimiliki secara langsung oleh pasar modern. Lokasi yang strategis, area perjualan yang luas, keragamaan barang yang lengkap, harga yang rendah, sistem tawar- menawar yang menunjukan keakraban antara penjual dan pembeli. Berbeda dengan pasar modern yang memaksa konsumen untuk mematuhi harga yang sudah dipatok. Selain keunggulan tersebut, pasar tradisional juga merupakan salah satu pendongkrak ekonomi kalangan menengah ke bawah dan jelas memberikan efek yang baik bagi negara. Pasar tradisional dengan segala tradisinya perlu dipertahankan, namun seiring perkembangan budaya masyarakat saat ini sudah mulai bergeser dan beralih ke pasar modern sehingga pasar tradisional tidak hanya menghadapi persaingan antar sesama pasar tradisional tetapi juga pasar modern, 
sehingga membuat kondisi pasar tradisional saat ini semakin terancam.

Pasar tradisional masih banyak terdapat di berbagai daerah di Indonesia, Salah satunya ialah di Kabupaten Katingan. Pasar tradisional di Kabupaten Katingan tersebut memegang peranan penting bagi perekonomian masyarakat di Kabupaten Katingan dan pasar tradisional tersebut menjadi salah satu sumber Pendapatan Asli Daerah (PAD). Sumber pemasukan dari pasar tradisional antara lain berasal dari retribusi pelayanan pasar seperti penyewaan los, kios, pelataran dan perpanjangan surat hak penempatan. Hal ini membuktikan bahwa kehadiran pasar tradisional di Kabupaten Katingan tidak dapat dipandang sebalah mata karena mampu menyumbang untuk pendapatan asli daerah Kabupaten Katingan.

Permasalahan yang terjadi di pasar tradisional, Pemerintah Kabupaten Katingan melalui Dinas Koperasi, Usaha Kecil Menengah, Perdagangan dan Perindustrian masih belum maksimal mengelola sarana dan prasarana pasar tradisional tersebut, karena masih adanya pasar tradisional yang belum direnovasi dan direvitalisasi, baik dari segi bangunan, penataan pedagang maupun sarana dan prasarana lainnya. Keberadaan pedagang kreatif lapangan (PKL) di sisi luar bangunan pasar juga merupakan salah satu masalah yang dihadapi Pasar Kereng Pangi. Kehadiran PKL menambah kesan kumuh dan semrawut yang biasanya mewarnai Pasar Kereng Pangi dan mengancam keberadaan pedagang yang menyewa kios dan lapak di pasar tradisional tersebut. Pasar tersebut merupakan pasar tradisional dengan kondisi luasan pasar dan lahan parkir yang kurang memadai dibandingkan pasar tradisional lainnya.

Menurut Hasibuan (2016:2), “manajemen adalah ilmu dan seni mengatur proses pemanfaatan sumber daya manusia dan sumber-sumber lainnya secara efektif dan efisien untuk mencapai suatu tujuan tertentu".

Kemudian menurut Stoner dalam Handoko (2016:8) mengatakan manajemen adalah proses perencanaan, pengorganisasian, pengarahan, dan pengawasan usahausaha para anggota organisasi dan penggunaan sumber daya-sumber daya organisasi lainnya agar mencapai tujuan organisasi yang telah ditetapkan.

Menurut Samuelson dan Nordhaus (2003:29), mengatakan "pasar merupakan tempat di mana para pembeli dan para penjual berinteraksi menentukan harga dan mengadakan pertukaran barang dan jasa". Selanjutnya, menurut Suyanto Nuhadi dalam Gemora Lorensa (2014:14), "pasar dalam bahasa sehari-hari diartikan sebagai tempat bertemunya penjual dan pembeli. Sedangkan dalam ilmu ekonomi pasar diartikan sebagai proses terjadinya interaksi antara penjual dan pembeli untuk mencapai kesepakatan harga dan jumlah barang atau jasa yang diperjualbelikan”.

Pasar tradisional adalah pasar yang dibangun dan dikelola oleh Pemerintah, Pemerintah Daerah, Swasta, Badan Usaha Milik Negara dan Badan Usaha Milik Daerah termasuk kerjasama dengan swasta dengan tempat usaha berupa toko, kios, los dan tenda yang dimiliki/dikelola oleh pedagang kecil, menengah, swadaya masyarakat atau koperasi dengan usaha skala kecil, modal kecil dan dengan proses jual beli barang dagangan melalui tawar menawar.

Pasar modern adalah pasar atau toko dengan sistem pelayanan mandiri, menjual berbagai jenis barang secara eceran yang berbentuk Minimarket, Supermarket, Department Store, Hypermarket ataupun grosir yang berbentuk Perkulakan. Adapun ritel modern yang diatur keberadaan lokasinya bahwa minimarket boleh berlokasi pada setiap sistem jaringan jalan, termasuk sistem jaringan jalan lingkungan pada kawasan pelayanan lingkungan (perumahan) di dalam kota/perkotaan. Berdasarkan luas lantai toko minimarket memiliki luas lantai $<400 \mathrm{~m} 2$.

I. Penerapan Profesionalisme Manajemen Pasar Yang Lebih Profesional Dengan Struktur Organisasi Dan Deskripsi Tugas Yang Jelas Untuk Setiap Jabatan.

2. Standar Operating Procedure (SOP) Manajemen Pasar, 
Peningkatan Mutu Dan Pembenahan Pengaturan Sarana Fisik Pasar

\section{METODOLOGI}

Dalam penelitian ini peneliti menggunakan metode penelitian kualitatif. Metode ini digunakan untuk mengungkapkan permasalahan yang ada serta mendapatkan gambaran yang mendalam terhadap permasalahan yang sedang diteliti dengan melakukan pengkajian objek yang alamiah dan apa adanya tanpa melakukan manipulasi terhadap permasalahan maupun keadaan.

\section{HASIL DAN PEMBAHASAN}

Pembahasan mengenai hasil penelitian ini berdasarkan teori fungsi manajemen menurut George R. Terry (Manullang,2012:7) yang terdiri dari Planning, Organizing, Actuating dan Controlling (POAC), yaitu sebagai berikut:

I. Perencanaan (Planning)

Berdasarkan hasil penelitian berkenaan dengan perencanaan ditemukan bahwa perencanaan dalam pembinaan dan penataan pedagang sudah dilakukan oleh Dinas Koperasi, Usaha Kecil Menengah, Perdagangan dan Perindustrian Kabupaten Katingan, hal ini dapat dilihat dengan dilakukannya pengumpulan datadata yang relevan di lapangan untuk dilakukan pengujian guna menjawab permasalahan yang terjadi kemudian disusun dalam bentuk langkahlangkah untuk melakukan penataan dan pembinaan kepada pedagang agar terciptanya ketertiban pedagang di pasar tersebut.

Selain melakukan perencanaan penataan dan pembinaan pedagang, Dinas Koperasi, Usaha Kecil Menengah, Perdagangan dan Perindustrian Kabupaten Katingan juga telah melakukan perencanaan pembangunan sarana dan prasarasana pasar yang dilakukan dengan melakukan pengajuan anggaran serta menyusun alternatif-alternatif baru untuk membangun dan merevitalisasi kembali Pasar Kereng Pangi. Pada saat proses penelitian ini peneliti juga mendapati fakta di lapangan bahwa sarana dan prasarana Pasar Kereng Pangi masih belum memadai, hal ini dapat dilihat dengan tidak adanya lahan parkir, luasan tanah yang sempit dan bentuk bangunan pasar yang tidak sesuai dengan yang diinginkan oleh pedagang dan pembeli.

2. Pengorganisasian (Organizing)

Berdasarkan hasil penelitian ditemukan bahwa pengelolaan Pasar Kereng Pangi yang dikelola oleh Dinas Koperasi, Usaha Kecil Menengah, Perdagangan dan Perindustrian Kabupaten Katingan dalam hal ini dilakukan oleh Bidang Perdagangan sampai pada saat ini masih belum melakukan pembentukan pengurus pasar yang bertanggung jawab dalam pengelolaannya, sehingga juga menjadi kendala dalam pengelolaan Pasar Kereng Pangi untuk tercapainya ketertiban dan terkelolanya dengan baik pasar tersebut.

3. Pengarahan (Actuating)

Diperoleh bahwa upaya pengarahan dalam pengelolaan Pasar Kereng Pangi sudah dilakukan oleh Dinas Koperasi, Usaha Kecil Menengah, Perdagangan dan Perindustrian Kabupaten Katingan, hal ini dapat diketahui dari upaya yang telah dilakukan dengan menggerakkan dan mengarahkan pegawai Bidang Perdagangan agar dapat melaksanakan tugasnya dengan baik yang berkenaan dengan pasar dan telah bekerjasama dengan Satuan Polisi Pamong Praja Kabupaten Katingan untuk dapat bersama-sama dalam memberikan arahan dan sosialisasi kepada pedagang di Pasar Pangi agar dapat tertib dalam melakukan aktifitasnya

4. Pengawasan (Controlling)

Ditemukan bahwa proses pengawasan dalam pengelolaan Pasar Kereng Pangi sudah 
dilakukan oleh Dinas Koperasi, Usaha Kecil Menengah, Perdagangan dan Perindustrian Kabupaten Katingan, hal ini dapat diketahui dari proses pengawasan langsung yang dilakukan dengan langsung turun ke lapangan bersama intansi lain untuk memantau aktifitas pedagang yang berjualan di pasar tersebut. Sedangkan pengawasan tidak langsung dilakukan dengan selalu menerima informasi dan laporan dari masyarakat dan atau dari media massa baik online ataupun cetak yang berkaitan dengan Pasar Kereng Pangi.

\section{KESIMPULAN}

Dalam Perencanaan, Dinas Koperasi, Usaha Kecil Menengah, Perdagangan dan Perindustrian Kabupaten Katingan dalam Pengelolaan Pasar Kereng Pangi adalah dengan melakukan pembinaan dan penataan pedagang serta mengajukan anggaran pada tahun berikutnya untuk merevitalisasi pasar. Kendala yang dihadapi yaitu keterbatasan anggaran dan lahan yang sempit untuk pengembangan pasar lebih lanjut serta bentuk bangunan pasar yang masih tidak sesuai dengan yang diinginkan oleh pedagang, sehingga pencapaian tujuan belum dapat dicapai secara maksimal. Kemudian, masih belum maksimal dalam Pengelolaan Pasar Kereng Pangi, terlihat dari koordinasi yang belum baik antara pihak dinas dengan pihak desa setempat, serta belum adanya pembentukan pengurus pasar menjadi kendala dalam mewujudkan ketertiban pedagang dan terkelolanya dengan baik Pasar Kereng Pangi.

Peraturan daerah dalam pengelolaan pasar dan penataan pedagang di Kabupaten Katingan, sehingga sampai pada saat ini belum pernah dilakukan penertiban dan memberikan sanksi yang tegas kepada para pedagang yang tidak tertib oleh pihak dinas dan isntansi terkait. Kemudian, dalam Kebersihan Pasar, Pasar Kereng Pangi dapat dikatakan masih belum bersih hal ini dapat dilihat dari masih adanya sampah yang ditinggalkan pedagang pada saat berjualan di pinggir jalan, serta tidak ada petugas khusus kebersihan yang menangani pasar.

\section{REFERENSI}

Gemora Lorensa. 20I4. Implementasi Kebijakan Retribusi Pelayanan Pasar Di Kabupaten Katingan Provinsi Kalimantan Tengah. Tidak diterbitkan.

Ghony, M. Djunaidi dan Almanshur, Fauzan. 2016. Metodologi Penelitian Kualitatif. Yogyakarta : ARRUZZ MEDIA

Hasibuan, Malayu S.P. 2016. Manajemen (Dasar, Pengertian, dan Masalah). Jakarta: Bumi Aksara.

Handoko, T. Hani. 2016. Manajemen. Yogyakarta : BPFE.

Manullang. M. 20I2. Dasar-Dasar Manajemen. Yogyakarta : Gadjah Mada University Press.

Peraturan Presiden Nomor II2 Tahun 2007 Tentang Penataan dan Pembinaan Pasar Tradisional, Pusat Perbelanjaan dan Toko Modern.

Peraturan Daerah Nomor : 4 Tahun 2010 Tentang Retribusi Pelayanan Pasar. Peraturan Bupati Katingan Nomor : 92 Tahun 2016 Tentang Kedudukan, Susunan Organisasi, Tugas dan Fungsi serta Tata Kerja Dinas Koperasi Usaha Kecil Menengah Perdagangan dan Perindustrian Kabupaten Katingan.

Samuelson dan Nordhaus. 2003. Ilmu Mikro Ekonomi. Jakarta : Media Global Edukasi.

Sugiyono. 20I0. Metode Penelitian Kuantitatif. Bandung : Alfabeta

Sugiyono. 2016. Metode Penelitian Kuantitatif, Kualitatif, dan R\&D. Bandung : Alfabeta.

Torang, Syamsir. 2014. Organisasi dan Manajemen. Bandung : Alfabeta.

Undang-undang Nomor : 7 Tahun 214 Tentang Perdagangan. Undang-undang Nomor : 23 Tahun 2014 Tentang Pemerintahan Daerah. 
Pencerah Publik, Volume 4 Issue I April 20I7, Page : 6- 10.

P-ISSN: 2407-3873

Waluyo. 2007. Manajemen Publik (Konsep, Aplikasi dan Implementasinya dalam Pelaksanaan Otonomi Daerah). Bandung : Mandar Maju.

Yahya, Yohannes. 2006. Pengantar manajemen. Yogyakarta : Graha ilmu.

10 